Pankaj Koparde ${ }^{1 * \pi}$, Sridhar Halali2", Ashish Tiple ${ }^{3}$, Parag Ranganekar ${ }^{4}$, Amol Sonawane ${ }^{5}$, Arajush Payra ${ }^{6}$, Prosenjit Dawn ${ }^{7}$, Ashwini Raju ${ }^{8}$ and K.A. Subramanian ${ }^{9}$

\title{
Lost in Time: Re-description and Ecological Re-assessment of two Indian Endemic Elattoneura Cowley, 1935 (Platycnemididae) Damselflies
}

"These authors contributed equally to this work

https://doi.org/10.23797/2159-6719_24_6

Received: 3 June 2020 - Accepted: 30 November 2020 - Published: 11 August 2021

\begin{abstract}
The Indian Elattoneura are a difficult group to identify due to their extreme morphological similarity and sparse information in identification keys and on geographical distribution. The ambiguity is prominent among two Peninsular Indian Elattoneura species, E. nigerrima (Laidlaw, 1917) and E. tetrica (Laidlaw, 1917), described a hundred years ago. Both species were described based on male specimens with scant information on their females. The species are IUCN Red-listed, E. nigerrima (Data Deficient) and E. tetrica (Least Concern). Hitherto it was thought that E. nigerrima was smaller than E. tetrica and both have non-overlapping geographical distribution. Here, we re-describe both sexes of E. nigerrima; E. tetrica along with morphometric data and geospatial analysis. We found that E. nigerrima is significantly larger than E. tetrica. The species are largely allopatric in distribution, with the former having a much wider spatial distribution than previously thought. Based on our geospatial analysis, we provide occurrence data useful for the future IUCN assessments of E. nigerrima and E. tetrica. We highlight the importance of updating taxonomic status information and data on spatiotemporal distribution to proceed with the conservation of endemic insects such as Elattoneura damselffies. Our study indicates ecological and threat assessments of Indian Odonata species are urgently needed.
\end{abstract}

Keywords: Odonata, dragonfly, citizen science, conservation, Morphometry, re-description, Peninsular India, threadtails

\section{Introduction}

Extreme morphological similarity among species often hinders accurate identification. Ambiguity in identification can result in severely erroneous data on the natural history and ecology (Chesters, 2017). If the species of interest are rare, endemic or endangered, such taxonomic ambiguities can severely hamper undertaking conservation measures (reviewed in Bickford et al., 2007; Delić et al. 2017). Misidentification problems are often encountered in tropical insects as the majority of the groups exhibit a high level of cryptic diversity; therefore accurate taxonomic identification of such species takes an enormous amount of expertise, time, cost, and human resources (Stork, 1988; Gadagkar et al., 1989; Godfray et al., 1999). Improper taxonomic identification of species may severely affect the assessment of conservation status of many taxa (Cardoso et al. 2011, Chenuil et al.,

1 School of Ecology \& Environmental Management, Faculty of Sustainability Studies, MIT World Peace University, Kothrud, Pune, Maharashtra, India.

2 Department of Zoology, University of Cambridge, Cambridge, CB23EJ, UK.

3 PG Department of Zoology, Vidyabharati College, Seloo, Wardha, Maharashtra, India.

4 Foundation for Environment Research Conservation, No. 407, III-A, Susheela Seawinds, Alto-Vaddem, Vasco-da-Gama, Goa, India.

5 Jijamata Mahavidyalaya, Sarati, Indapur, Pune, Maharashtra, India.

6 Ramnagar, Purba Medinipur, West Bengal, India.

7 Department of Zoology, Shyampur Siddheswari Mahavidyalaya, Ajodhya, Howrah, West Bengal.

8 Kalap Trust, G-207, Doon Trafalgar Extension, Dhoran Road, Village Dhorankhas, Pargana Parwadoon, Dehradun, Uttarakhand, India.

9 Southern Regional Centre, Zoological Survey of India, 130, Santhome High Road, Chennai, Tamil Nadu, India.

* corresponding author E-mail: pankajkopardefagmail.com (PK) 
2019, Sundar et al., 2020). Hence, obtaining thorough information, natural history and geographic distribution, and the construction of reliable taxonomic keys is necessary to significantly aid in longterm monitoring and designing appropriate conservation measures.

The genus Elattoneura Cowley, 1935 comprises 44 species worldwide (Paulson \& Schorr, 2020). Thirteen taxa (eleven species and two subspecies) have been recorded from the Indian Subcontinent, of which five species are known to be endemic to India (Prasad \& Varshney, 1995; Subramanian \& Babu, 2017; Mitra, 2002; Babu et al., 2013; Kalkman et al. 2020) (Supplementary Fig. 1, Supplementary Table 1). Elattoneura damselflies are distinguishable based on some of the key morphological characters such as body size and colour, wing venation, and peculiar hammer-of-revolver-shaped superior anal appendages (Fraser, 1933).
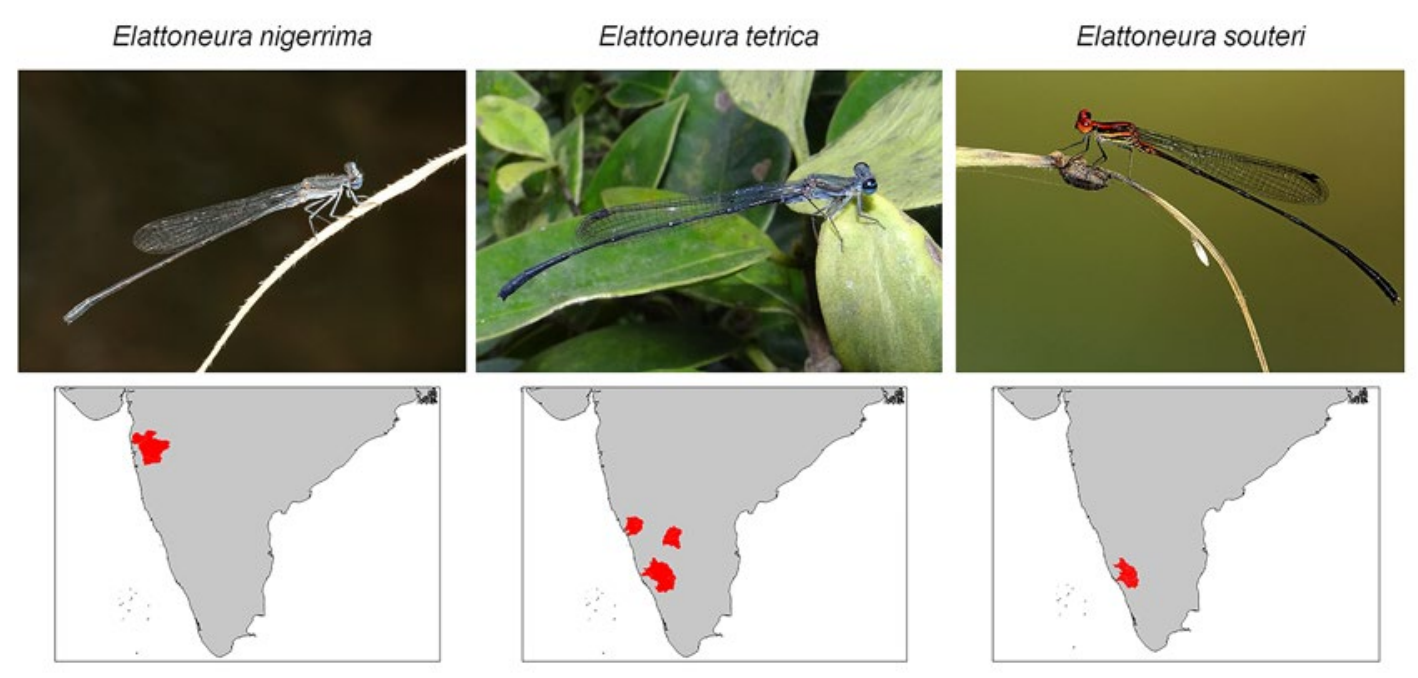

Figure 1. Peninsular Indian Elattoneura species show morphological similarities except in the case of $E$. souteri. The geographical distribution is as per IUCN (2015). Photo credits: E. nigerrima by Pankaj Koparde; E. tetrica by Prachi Mhaske; E. souteri by Risoon Thumboor.

Four Elattoneura species are found in Peninsular India. Among these, Elattoneura tetrica (Laidlaw, 1917), Elattoneura nigerrima (Laidlaw, 1917), and Elattoneura nihari (Mitra, 1995), are the most difficult to differentiate given the scanty and ambiguous taxonomic information provided in their original descriptions, and severe lack of data on their spatial distribution (Figure 1). The species, $E$. nigerrima can be easily confused with Pseudagrion hypermelas Selys, 1876 (Fraser 1933). Both, E. nigerrima and E. tetrica have been confused with Onychargia atrocyana (Selys, 1865) (Subramanian 2009, Babu et al. 2013). During our preliminary literature survey and museum studies, we observed that many specimens deposited in the national zoological collections at Kolkata labeled as $E$. nigerrima are misidentified. On citizen science forums, such as DragonflySouthAsia (https://www. facebook.com/groups/dragonflyindia) we observed a tremendous amount of confusion in naturalists and odonatologists regarding E. nigerrima and E. tetrica, which motivated us to pursue the study.

According to the IUCN Red List of Threatened Species, E. nigerrima (Kakkasery, 2013) and E. tetrica (Kakkasery, 2011) are Data Deficient and Least Concern, respectively. Both species were described around a century ago by Laidlaw (1917). The original description contains a meager description of overall morphology and illustrations of only lateral profiles of anal appendages of both the species, which are difficult to interpret. Laidlaw (1917) states that E. nigerrima is the smallest species in the entire genus. The revised description (Fraser, 1933) reads that E. tetrica can be distinguished from E. nigerrima by its larger size and higher nodal index (henceforth referred to as Fraser's size hypothesis). Fraser (1933) also states that E. tetrica is restricted to the Western Ghats, south of the Satara region, whereas E. nigerrima is distributed in the West and Central India, not descending south of Satara (henceforth referred to as Fraser's distribution hypothesis). Hence, based on the geographical distribution records in the literature, it can be assumed that the Satara region of the West- 
ern Ghats forms a virtual boundary to distinguish the two similar-looking species. The central Indian Elattoneura damselfly, E. nihari Mitra, 1995, was described based on a single specimen from Madhya Pradesh, India. Currently, E. nihari is known only from its type locality. No recent specimens of E. nihari were collected since its discovery (Dow, 2009), leaving a large spatio-temporal knowledge gap on the Peninsular Indian Elattoneura damselflies.

In the present study, we re-describe E. tetrica and E. nigerrima, after a gap of more than a century since their original descriptions and provide diagnostic characters to identify both the species in the field. Using quantitative morphology, a combination of field surveys and citizen science data, we test Fraser's size and distribution hypotheses. Here, we raise questions on the status of $E$. nihari and provide inputs for the assessment of the IUCN status of Peninsular Indian Elattoneura species.

\section{Methods}

\section{Sampling}

We conducted opportunistic sampling surveys across Peninsular India. During primary field surveys, we recorded E. nigerrima in 25 locations and E. tetrica in 5 locations, apart from the locations derived using citizen science portals (Supplementary Table 2). We collected 17 (14 males, three females) and 20 (17 males, three females) specimens of E. tetrica and E. nigerrima, respectively, from 10 different locations in Peninsular India (Supplementary Table 3), these were stored in absolute alcohol for lab-identification and further analysis. Male specimens of E. nigerrima $(\mathrm{n}=17)$ and E. tetrica $(\mathrm{n}=14)$ were used for comparative morphometry. We deposited all studied specimens for morphological re-description in public repositories. We deposited studied specimens of $E$. $n i$ gerrima in the collections of Post Graduate Department of Zoology, Vidyabharati College, Seloo, Wardha, Maharashtra (Registration numbers: four males - VBCS DZ/42, VBCS DZ/43, VBCS $\mathrm{DZ} / 44$, VBCS DZ/45, and one female - VBCS DZ/46) and the national zoological collections at Kolkata (Registration number: two males - 8253/H13). Specimens of E. tetrica studied are deposited in the national zoological collections at Kolkata (Registration numbers: two males and one female - 8252/H13). Some specimens used for morphometry were damaged during the handling procedure; hence we did not deposit them in public repositories. We initially identified the specimens based on the identification keys provided by Laidlaw (1917) and Fraser (1933). Additionally, we validated the identity of all the specimens by comparing them with high-resolution photographs of the holotype of E. nigerrima (Catalogue number: $\mathrm{BMNH}(\mathrm{E}) 1201776)$ and paratypes of $E$. tetrica (Catalogue numbers: BMNH(E)1201785, BMNH(E)1201786, BMNH(E)1201787) obtained from the British Museum of Natural History (BMNH), London. Our taxonomic descriptions and morphological terminologies follow Garrison et al. (2010). We also accessed the type specimen of $E$. nihari from the Zoological Survey of India (ZSI) (Catalogue number: 4096/H13), Kolkata, to update the information on its morphology and for comparing with our specimens. In addition to the field sampling, we used a citizen science approach to extend the scope of our survey. We used a virtual forum DragonflySouthAsia (https:/www.facebook.com/groups/dragonflyindia) and a curated database Odonata of India (Joshi et al., 2020) to retrieve data on the spatial distribution of Elattoneura damselflies.

\section{Morphometrics}

We measured twelve morphological variables in length ( $\mathrm{mm}$ ): head to the thorax, abdomen (including anal appendages), forewing, hindwing, total body (sum of thorax and abdomen), and lengths of abdominal segments, for carrying out morphometric analysis. Except for abdominal segments, all the measurements were carried out using a digital vernier caliper (Ocean $\left.{ }^{\circledR}\right)$ nearest to $0.01 \mathrm{~mm}$. We measured individual abdominal segments (2-7 and combined lengths of segments 8-10) by first photographing specimens using a digital SLR camera and then analyzing the images in Image J v1.48 
software (Schneider et al., 2012). We also carried out similar measurements for the type specimen of E. nihari. The E. nihari specimen was severely damaged; hence we could extract only limited morphometric data. All the measurements were taken in triplicates by one observer and the mean value was used in the final analysis. We took pictures of anal appendages using a Leica Stereo Zoom Microscope (Leica M205A) using the Leica application suite software (LAS v3.8).

We first checked for normality in the data using the Shapiro-Wilk test (Shapiro \& Wilk, 1965; Hanusz et al., 2016). We then used a two-sample t-test for testing the differences in morphological traits (thorax, abdomen, forewing, hindwing, total body length) between species (E. nigerrima and E. tetrica). We performed the Principal Component Analysis (PCA) to reduce the number of dimensions required to describe species variation. Before performing the PCA, we carried out Pearson's correlation analysis among all the variables and removed highly correlated variables (cut-off \pm 0.9 ). Following these criteria, we excluded the total body length and length of segment seven from the analysis. We restricted our analysis on males due to the higher sample size and also because taxonomic keys (Fraser, 1933) are based on male specimens. We used RStudio v1.0.143 (R Core Team, 2013) for the statistical analysis.

\section{Geospatial analysis}

We compared the geographical distribution for both species (E. nigerrima and E. tetrica) by plotting our records (Supplementary Table 2) on the map along with the species distribution map provided by IUCN (Kakkasery, 2011, 2013). We prepared the distribution maps using QGIS v.2.4.0 (QGIS Development Team, 2019) and the GeoCAT tool (http://geocat.kew.org/). We constructed a minimum convex polygon to measure the Extent of Occurrence (EOO). For the Area of Occupancy (AOO), we considered a grid cell of $2 \mathrm{~km} \mathrm{X} 2 \mathrm{~km}$ dimensions (Nelson et al. 2011). Based on the geospatial point locations, we derived elevation and climate data extracted from Chelsa climatology (Karger et al., 2017, https://chelsa-climate.org). The resolution of climate data is 30 arc seconds $(\sim 1 \mathrm{~km})$. The extracted data was first tested for normality using the Shapiro-Wilk test (Shapiro \& Wilk, 1965; Hanusz et al., 2016) before proceeding for statistical analysis.

\section{Results}

\section{Descriptive morphology of Elattoneura nigerrima (Laidlaw, 1917)}

Specimens examined: 4 Males, 1 Female, Pothara River, Nagri, Wardha, Maharashtra State (20.425, 78.8666, 209.5 masl), Coll. Ashish Tiple, 10.iv.2020. Registration numbers: 4 Males - VBCS DZ/42, VBCS DZ/43, VBCS DZ/44, VBCS DZ/45, and 1 female - VBCS DZ/46.

Adult male (Figure 2). (Abdomen $=25.47 \mathrm{~mm} \pm 0.2 \mathrm{~mm}$, Hindwing $=13.88 \mathrm{~mm}-16.23 \mathrm{~mm}$ ). Head: Labium brown, labrum blue, rest of the head blackish brown with pruinescence. Eyes: brown above and greenish-blue below separated by two narrow black equatorial bands. Thorax: Black; prothorax and synthorax are black dorsally; mesepimeron black; posterolateral suture is bordered by black with pruinescence; lower part of metepimeron pale brown with yellow on the ventral side (Supplementary Fig. 2). Legs: Black. Trochanter and coxa shaded with yellow; femora black with pruinescence; tibia yellow on flexor surface; femur and tibia with long black spines. Wings: Hyaline. Two antenodals and 9-12 postnodals in forewings, two antenodals and 8-11 postnodals in hindwings; anal crossvein lies between $1^{\text {st }}$ and $2^{\text {nd }}$ antenodal nervure; median space entire; anal bridge arising before anal crossvein and complete; arc proximal to $2^{\text {nd }}$ antenodal nervure, sectors of arc divergent from the origin; discoidal cell rectangular and discoidal field starting with a single row of rectangle-shaped cells; Cuii covering four cells in forewings and five in hindwings. Pterostigma brown framed with yellow enclosed by thick black nervures, more than half a cell long. Abdomen: Black dorsally. Segments 1 and 2 are black, yellowish laterally; segment 3-7 separated by the intersegmental ring and have small paired white spots posterolaterally; segment 7-10 entirely black. Anal appendages: Black, cerci broad at the base and narrowing at the apex. Cerci have two promi- 
nent ventrally projecting spines, paraprocts longer than cerci, curled upwards and inwards with an obtuse tip (Figure 3, Supplementary Fig. 3).

\section{Elattoneura nigerrima}
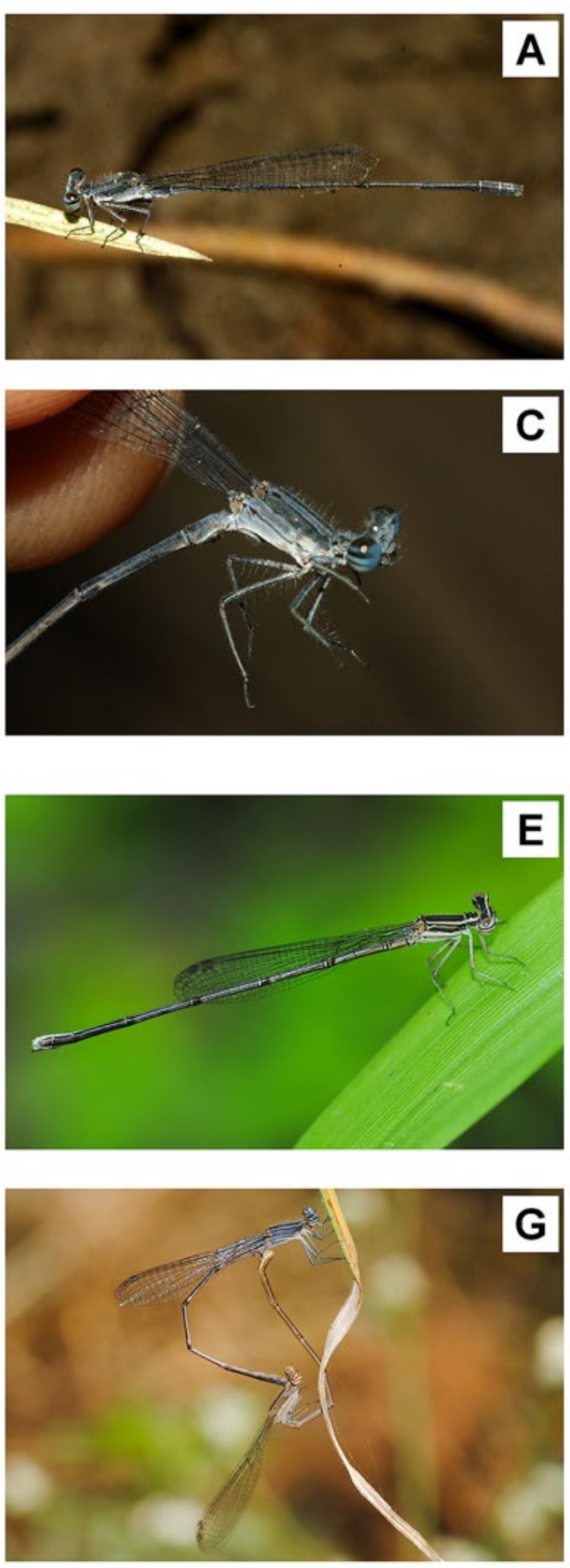

\section{Elattoneura tetrica}
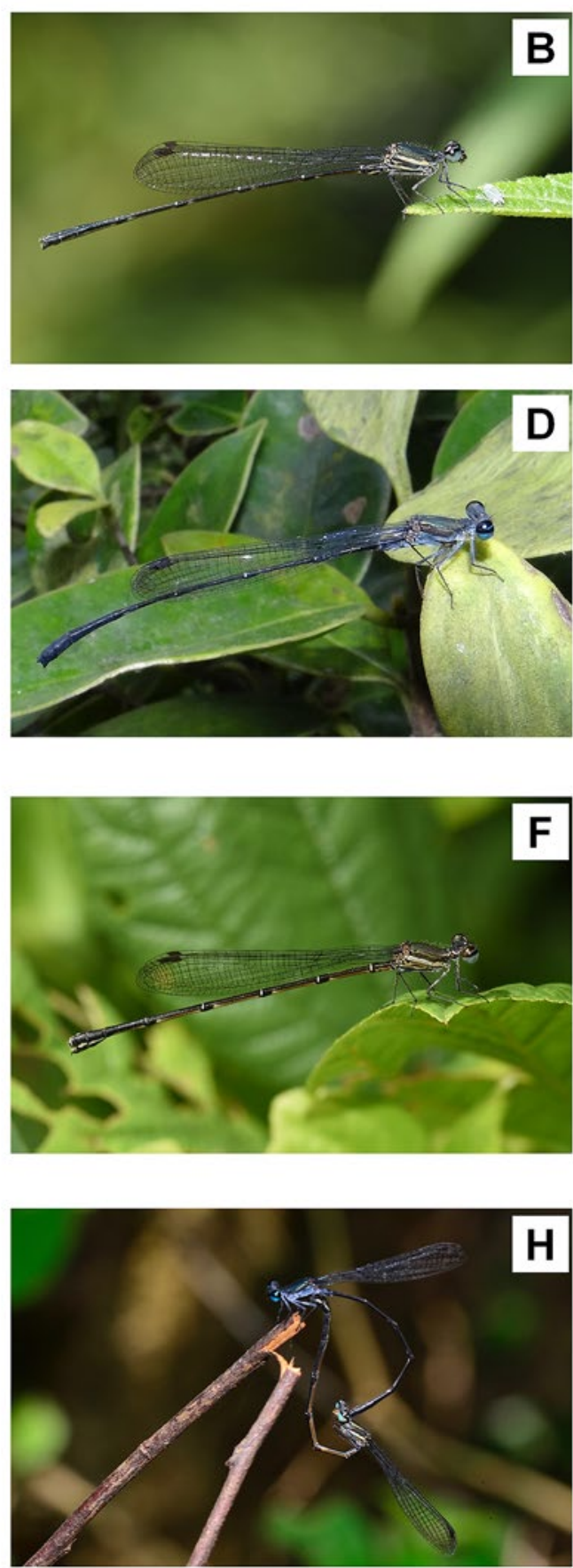

Figure 2. Field photographs of specimens of E. nigerrima and E. tetrica. A, B: fresh males; C, D: pruinosed males; E, F: females; G, H: copula. Photo credits: Elattoneura nigerrima (fresh male: Ashish Tiple, pruinosed male: Pankaj Koparde, female and copula: Dattaprasad Sawant) and E. tetrica (fresh male, female, and copula: Balachandran V., pruinosed male: Prachi Mhaske). 

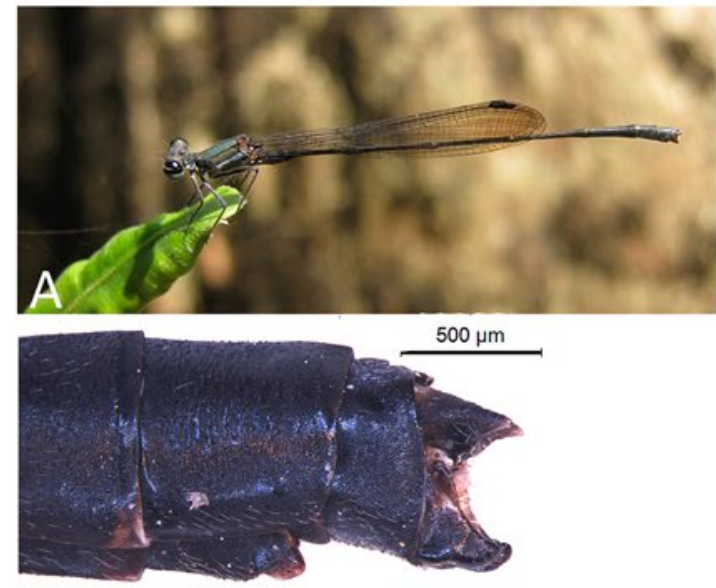

A.i
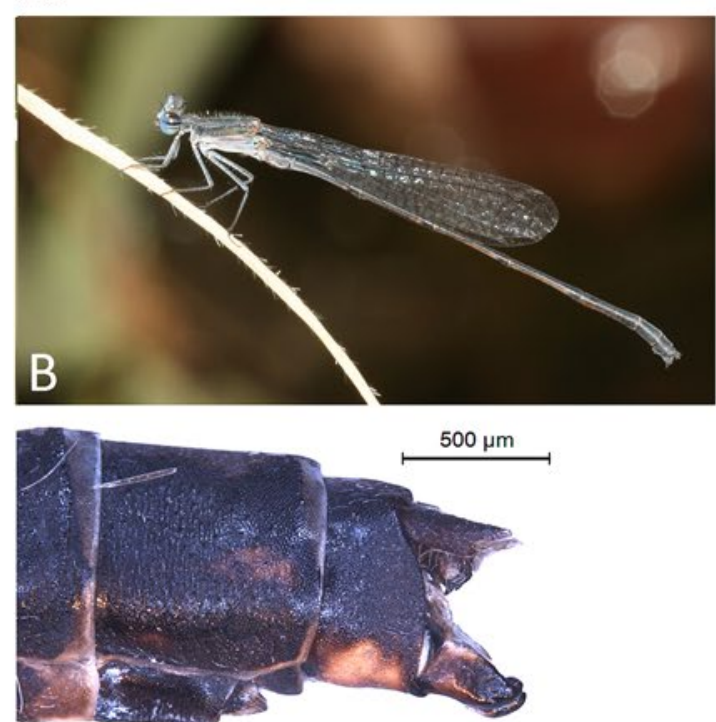

B.i
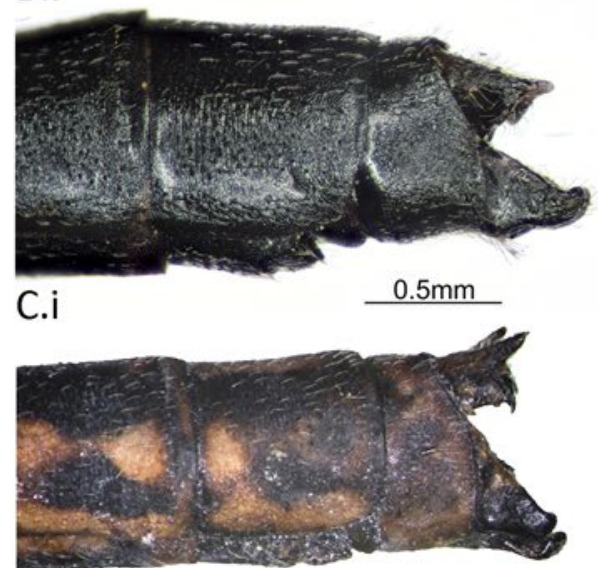

D.i

$1 \mathrm{~mm}$

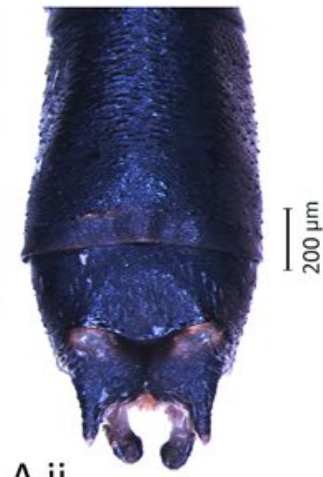

A.ii

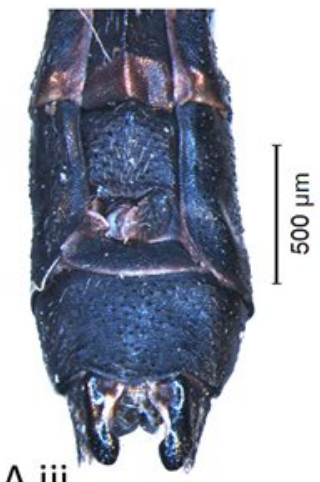

A.iii
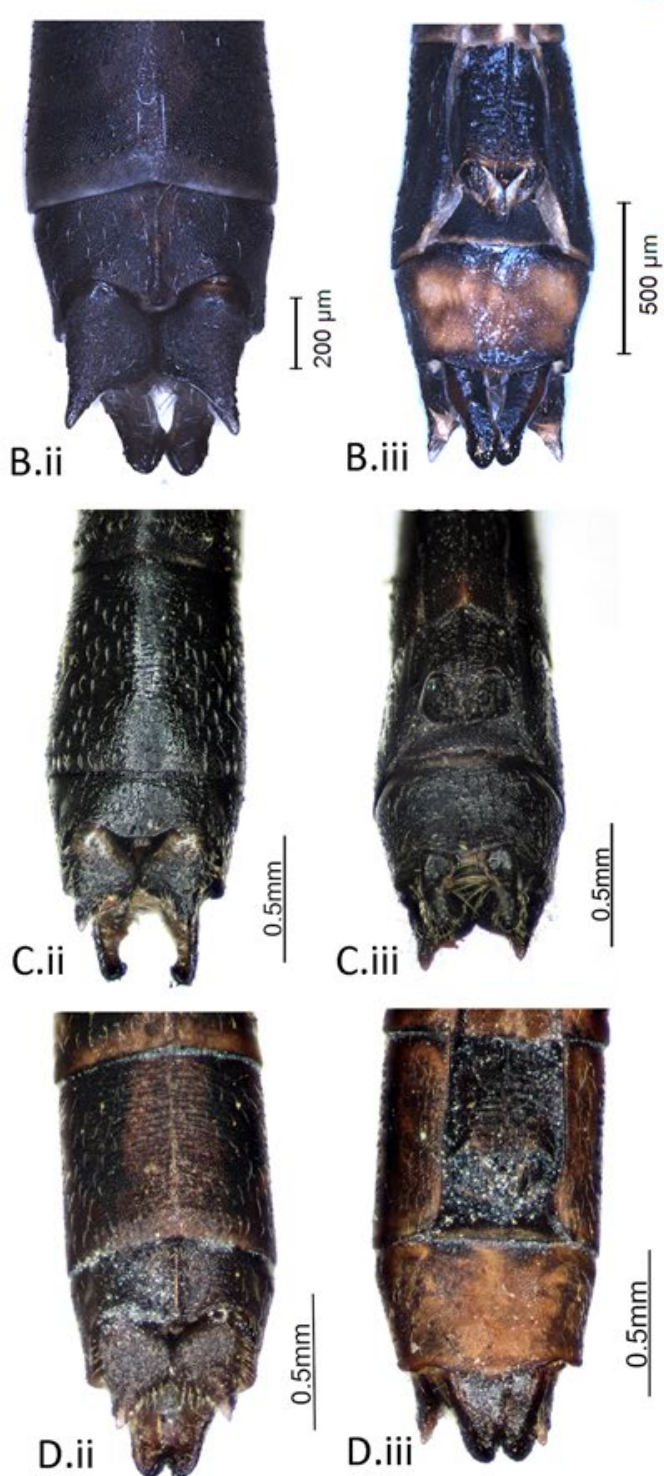

Figure 3. Profiles of anal appendages of E. tetrica and E. nigerrima. Numbers i, ii, iii represent lateral, dorsal, and ventral views of anal appendages. A: Elattoneura tetrica study specimen, B: Elattoneura nigerrima study specimen, C: Holotype E. nigerrima (catalogue: BMNH (E) 1201776), and D: Paratype E. tetrica (catalogue: BMNH (E) 1201785). 
Adult female (Figure 2). (Abdomen $=24.77 \pm 0.1 \mathrm{~mm}$, Hindwing $=14.38 \mathrm{~mm}-15.82 \mathrm{~mm})$. Head: Labrum pale blue, clypeus brown, frons pale brown or yellowish, pale yellow behind and in front interrupted by black band from eye to eye at the level of an anterior ocellus, base of antennae black. Eyes: Brown above and pale blue below separated by two narrow brown equatorial belts of which anterior belt runs eye to eye at the level of the base of antennas as a black band, narrow blue band above first equatorial belt on eyes is confluent with yellowish of the vertex. Thorax: Prothorax black dorsally; anterior lobe black dorsally with yellowish stripe laterally; posterior lobe of pro-thorax divided in the middle and forming two hornlike projections in lateral view (Supplementary Fig. 2). Synthorax black dorsally, mid-dorsal carina black, ante humeral stripe yellow followed by brown post humeral stripe, laterally black extends as far as the middle of mesepimeron, the lower half of mesepimeron and metepimeron yellow, black posterolateral suture, ventrally pale yellow. Legs: Yellow, femora blackish on extensor surface, tibiae yellow with pale brown on flexor surface, last segments of tarsi black. Wings: Pterostigma small, pale brown framed narrowly in yellow, approximately one cell long; two antenodals and 12 postnodals in forewings, two antenodals and 11 postnodals in hind wings; median space entire, discoidal cell rectangular; discoidal field with one row of rectangle-shaped cells; anal bridge complete and arises very close to the origin of anal cross-vein running parallel to discoidal cell; Cuii five cells long in fore wings and six cells long in hind wings. Abdomen: Black dorsally and yellowish laterally. Segments 3-6 with black sub-apical ring and with a yellow intersegmental ring; segment 7-10 with mid-dorsal yellow stripe which is expanding in segments 8, 9 and 10; yellow stripe running continuously from segment 8-10 laterally. Anal appendages: Conical, pale yellow.

\section{Descriptive morphology of Elattoneura tetrica (Laidlaw, 1917)}

Specimens examined: 2 Male, 1 Female, Collem, South Goa, Goa State (15.3382 N, 74.2480 E, 81 masl), Coll. Sridhar Halali and Dhiraj Halali, 20.v. 2014. Registration number: two males and one female - NZC-ZSI Registration no. 8252/H13.

Adult male (Figure 2). (Abdomen $=24.41 \pm 0.2 \mathrm{~mm}$, Hindwing $=17.11 \mathrm{~mm}-18.47 \mathrm{~mm})$. Head: Brown labium, dark brown labrum, and brown anteclypeus; rest of the head black. Eyes: capped with black and green below separated by a single broad black equatorial band. Thorax: Prothorax: Velvety black dorsally with thin pruinescence at sides and beneath, Synthorax: Velvety black dorsally with prominent mid-dorsal carina. The lower part of mesepimeron, posterolateral suture, and upper half of metepimeron is pruinosed, the lower half of the metepimeron and ventral side creamy white to pale yellow. Legs: Trochanter and femur of all legs black with pruinescence, tibiae yellow on flexor surface, tarsi black. Wings: Hyaline with apical ends enfumed with pale brown color. Two antenodals and 12-13 postnodals in fore wings, two antenodals and 10-12 postnodals in hind wings. Cubital and basal space entire. Anal bridge complete and emerging between two antenodals. Discoidal cell rectangular in shape, discoidal field starting with one row of rectangular-shaped cells. Sectors of arc divergent at the origin. Cuii three cells long in the forewing while four cells long in the hindwing. Pterostigma brown, framed in yellow surrounded by thick black nervures. Usually one to one and a half cells long. Abdomen: Segment 1 black dorsally and pruinosed heavily, segment two black dorsally with yellow on the ventral border. Segment 3-7 black dorsally and ventrolaterally with a yellow intersegmental ring. Segment 8,9,10 entirely black. Anal appendages: Black, cerci longer than paraprocts. Cerci acutely pointed at the apex with a bifid ventral spine. Paraprocts are broad at the base tapering to the apex, which is curved inwards (Figure 3, Supplementary Fig. 4).

Adult female (Figure 2). (Abdomen $=23.73 \pm 0.2 \mathrm{~mm}$, Hindwing $=16.33 \mathrm{~mm}-17.32 \mathrm{~mm})$. Head: Labium pale brown, labrum, and anteclypeus brown, postclypeus and frons bluish. The rest of the head black, traversed at the level of the anterior ocellus by a narrow yellow stripe from eye to eye. Eyes black above and pale green below separated by a single black equatorial belt. Thorax: Prothorax: Dark brown to black dorsally. Middle lobe with a large pale greenish-white spot on either side, followed by another small yellowish spot from behind. The posterior lobe of the prothorax interrupted in the middle, thus divided into two flap-like projections. Two additional dorsal finger-like projections originate from the base of the posterior lobe; these appear like forwardly directed horns in lateral view. Synthorax: Black dorsally extending up to anterolateral suture, incomplete narrow 
yellow ante humeral stripe; mesepimeron and metepimeron yellow interrupted by black postero-lateral suture, yellow ventrally. Wings: Similar to male but slightly less enfumed; 2 antenodals and 12 postnodals in forewings and 11 postnodals in hindwings; pterostigma pale yellow thinly framed in yellow surrounded by black nervures; anal bridge complete; Cuii three cells long. Legs: Yellow throughout with hinder surface of femora, flexor surface of tibiae and tarsi black. Abdomen: Black dorsally and yellow laterally; segment 3-6 with broad black apical rings laterally; segment 2-6 separated by a yellow intersegmental ring; segment 8-9 with elongated yellow stripe laterally, segment 9 with small yellow spot dorsally, segment ten black. The comparative morphological description of E. nigerrima and E. tetrica are summarized in Table 1.

Table 1. Some of the key morphological characters to differentiate between E. nigerrima and E. tetrica.

\begin{tabular}{|c|c|c|}
\hline Character & E. nigerrima & E. tetrica \\
\hline Wings & $\begin{array}{l}\text { Wings completely hyaline in both } \\
\text { male and female }\end{array}$ & $\begin{array}{l}\text { pical ends of wings are enfumed in males } \\
\text { nd less enfumed in females }\end{array}$ \\
\hline Eyes & $\begin{array}{l}\text { Both male and female with two thin } \\
\text { black equatorial bands on eyes }\end{array}$ & $\begin{array}{l}\text { Both male and female with a single broad } \\
\text { equatorial band on eyes }\end{array}$ \\
\hline Cuii & $\begin{array}{l}\text { Cuii five cells long in forewings and } \\
\text { six in hindwings }\end{array}$ & $\begin{array}{l}\text { Cuii three cells long in forewings and four } \\
\text { in hindwings }\end{array}$ \\
\hline Prothorax & $\begin{array}{l}\text { The posterior lobe of prothorax in } \\
\text { females appears like two simple } \\
\text { hornlike projection in lateral view }\end{array}$ & $\begin{array}{l}\text { The posterior lobe of the prothorax } \\
\text { has two additional prominent dorsal for- } \\
\text { wardly bent horn-like projections visible in } \\
\text { lateral view }\end{array}$ \\
\hline Thorax & $\begin{array}{l}\text { Thorax is more yellow in females } \\
\text { having complete antehumeral and } \\
\text { posthumeral stripe }\end{array}$ & $\begin{array}{l}\text { Thorax is more blackish (entire dorsal to } \\
\text { mesepimeron) in females having incom- } \\
\text { plete antehumeral and absence of post- } \\
\text { humeral stripe }\end{array}$ \\
\hline $\begin{array}{l}\text { Abdomen } \\
\text { (S3-S7) }\end{array}$ & $\begin{array}{l}\text { Black sub-apical rings are absent or } \\
\text { greatly reduced in females }\end{array}$ & $\begin{array}{l}\text { Segment } 3-7 \text { with broad black sub-apical } \\
\text { rings in females }\end{array}$ \\
\hline $\begin{array}{l}\text { Abdomen } \\
\text { (S8-S10) }\end{array}$ & $\begin{array}{l}\text { Abdominal segments in females are } \\
\text { (segment } 8,9,10 \text { ) are yellow }\end{array}$ & $\begin{array}{l}\text { Terminal abdominal segments in females } \\
\text { are black }\end{array}$ \\
\hline Paraprocts & Very close with no gap in between & Well separated with a wide gap in between \\
\hline Cerci & With two prominent spines ventrally & $\begin{array}{l}\text { Only one spine is prominent, but the wavy } \\
\text { shape of the flap appears like an obtuse } \\
\text { projection laterally }\end{array}$ \\
\hline
\end{tabular}

\section{Comparative morphometry of E. nigerrima and E. tetrica}

All the measured data were normally distributed (Shapiro Wilk's test; for all variables $\mathrm{P}>0.05$ ). Results of PCA showed that both the species can be separated based on the quantitative assessment of morphological traits (Supplementary Fig. 5). The first principal component (PC1) captured 54.45\% and the second $27.27 \%$ of the total variation in the data. $\mathrm{PC} 1$ was primarily dominated by the hindwing $(\mathrm{PC}$ loading $=0.69)$ and forewing $(\mathrm{PC}$ loading $=0.67)$ lengths and $\mathrm{PC} 2$ was dominated by abdomen length with a PC loading of 0.94 (Supplementary Fig. 5, Supplementary Table 4). Overall, E. nigerrima $(30.10 \mathrm{~mm} \pm 1.01 \mathrm{~mm})$ was larger than E. tetrica $(29.31 \mathrm{~mm} \pm 0.73 \mathrm{~mm})$ (Two-sample ttest; total body length, $\mathrm{t}=-2.48, \mathrm{P}=0.01)$. Comparison of abdominal lengths revealed that $E$. nigerrima $(25.22 \mathrm{~mm} \pm 0.82 \mathrm{~mm})$ was larger than E. tetrica $(24.37 \mathrm{~mm} \pm 0.65 \mathrm{~mm})$ (Two-sample t-test; $\mathrm{t}$ $=-3.18, \mathrm{P}<0.01)$. While, E. tetrica was larger in terms of forewing $(17.08 \mathrm{~mm} \pm 0.68 \mathrm{~mm})$ and hindwing $(16.24 \mathrm{~mm} \pm 0.69 \mathrm{~mm}$ ) lengths as compared to E. nigerrima (Forewing $=16.00 \mathrm{~mm} \pm 0.65$ 
$\mathrm{mm}$; hindwing $=15.06 \mathrm{~mm} \pm 0.63 \mathrm{~mm}$ ) (Two-sample t-test; forewing length, $\mathrm{t}=4.44, \mathrm{P}<0.01$; hindwing length, $\mathrm{t}=4.87, \mathrm{P}<0.01$ ). The difference in thorax length was not significant (Two-sample ttest; thorax length, $\mathrm{t}=0.60, \mathrm{P}=0.54$ ) (Table 2, Supplementary Fig. 6). Post-nodal nervures of $E$. $n i$ gerrima varied from 9-13 in the fore wing and 8-11 in the hind wing, whereas that of E. tetrica, varied from $12-13$ and $10-12$ in the fore wing and hind wing respectively.

Table 2. Morphometric measurements laverage $(\mathrm{mm}) \pm$ SD $(\mathrm{mm}))$ of male specimens of Peninsular Indian Elattoneura spp. $\mathbf{N}$ = Sample size.

\begin{tabular}{lccc}
\hline Variable & E. nigerrima $(\mathbf{N}=17)$ & E. tetrica $(\mathbf{N}=14)$ & E. nihari $(\mathbf{N}=\mathbf{1})$ \\
\hline Thorax length & $4.87 \pm 0.33$ & $4.94 \pm 0.21$ & 4.27 \\
Total length & $30.10 \pm 1.01$ & $29.31 \pm 0.73$ & - \\
Abdomen length & $25.22 \pm 0.82$ & $24.37 \pm 0.65$ & - \\
Forewing length & $16.00 \pm 0.65$ & $17.08 \pm 0.68$ & 15.19 \\
Hindwing length & $15.06 \pm 0.63$ & $16.24 \pm 0.69$ & 14.31
\end{tabular}

\section{Spatiotemporal distribution and climatic space of E. nigerrima and E. tetrica}

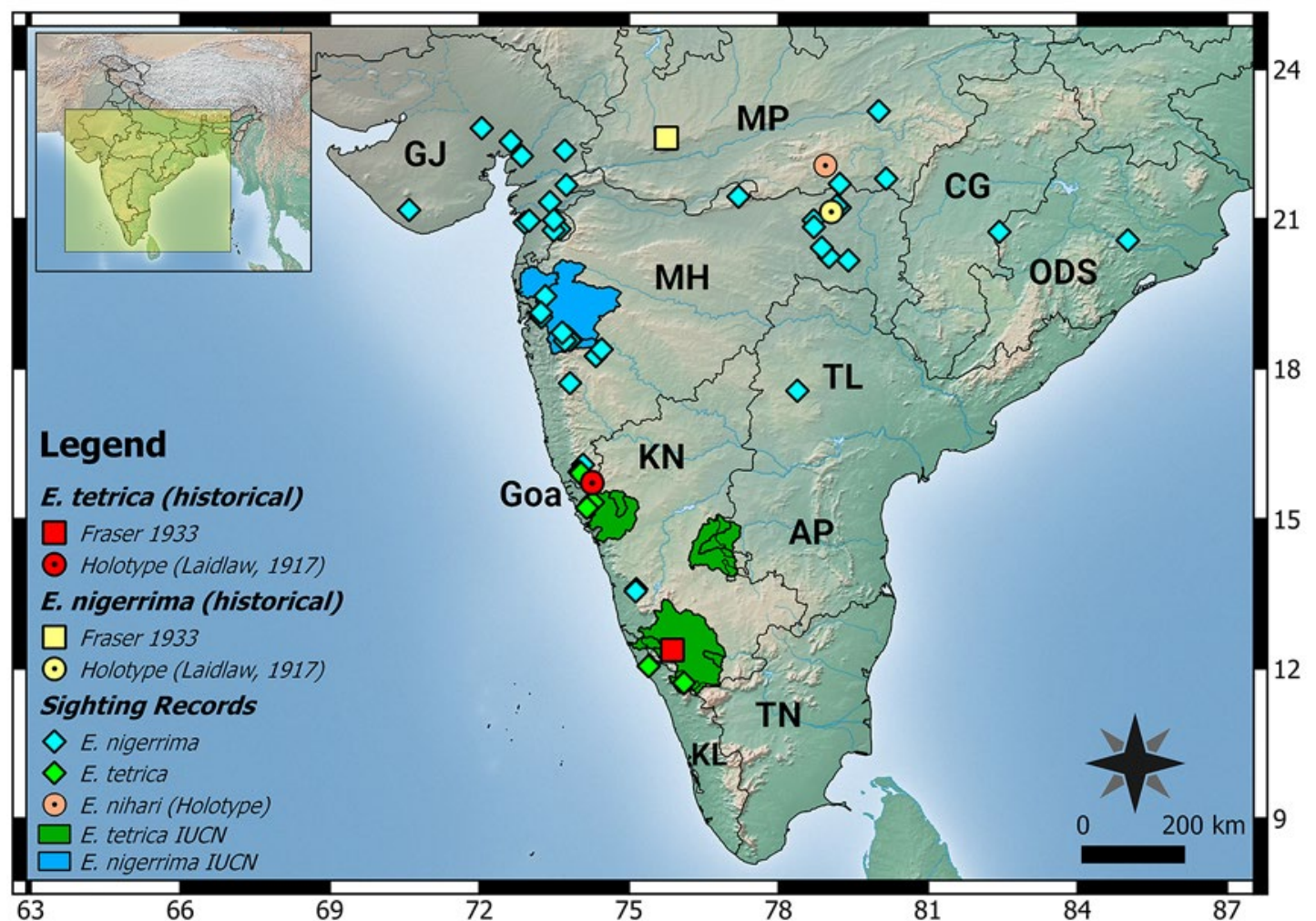

Figure 4. Map showing E. nigerrima and E. tetrica overlap in spatial distribution. GJ: Gujarat; MP: Madhya Pradesh; CG: Chhattisgarh; ODS: Odisha; AP: Andhra Pradesh; TL: Telangana; TN: Tamil Nadu; KL: Kerala; KN: Karnataka; MH: Maharashtra. 
In the current study, E. nigerrima was recorded south of the Satara region in the Eastern catchment of the Western Ghats (Figure 4) as far as $480 \mathrm{~km}$ south of Satara as the crow flies. In addition, some specimens of E. nigerrima were photographed or collected from Odisha, Gujarat, and Telangana, which are new distribution records for E. nigerrima in eastern and western India. E. tetrica is confined to the Western Ghats, primarily in the Western catchment. We did not encounter E. nihari during sampling. Spatially derived data are listed in Supplementary Table 5. Both the species were observed at mid-elevations (372 \pm 256 masl for E. nigerrima, $497 \pm 363$ masl for E. tetrica). The climatic space for both the species differed. E. nigerrima occurred in relatively drier parts of the country with moderate to low rainfall (average annual temperature $=29.69{ }^{\circ} \mathrm{C} \pm 3.4{ }^{\circ} \mathrm{C}$, average annual precipitation $=1473 \mathrm{~mm} \pm 923 \mathrm{~mm}$ ) compared to $E$. tetrica (average annual temperature $=$ $26.95^{\circ} \mathrm{C} \pm 2.5^{\circ} \mathrm{C}$, average annual precipitation $=3178 \mathrm{~mm} \pm 585 \mathrm{~mm}$ ) (Kruskal-Wallis test; average annual temperature, $\mathrm{Hc}=6.62, \mathrm{P}=0.01$; average annual precipitation, $\mathrm{Hc}=24.73, \mathrm{P}<<0.001)$. The calculated EOO $\left(891,084 \mathrm{~km}^{2}\right.$ for E. nigerrima and $21,735 \mathrm{~km}^{2}$ for E. tetrica) and AOO $\left(172 \mathrm{~km}^{2}\right.$ for E. nigerrima and $36 \mathrm{~km}^{2}$ for E. tetrica) for the two species differed. E. nigerrima was perennial with the sighting frequency peaking during the Post Monsoon. E. tetrica showed a bimodal seasonality with frequency peaking at the onset of Post Monsoon and end of summer seasons (Supplementary Fig. 7)

\section{Discussion}

\section{Resolving taxonomic ambiguity between E. nigerrima and E. tetrica and comments on E. nihari}

Our results indicate that field identification of E. nigerrima and E. tetrica is possible based on morphological characters using two prominent features viz, eye bands and thoracic markings in live specimens. As a confirmatory test, the shape of anal appendages, especially paraprocts, can be used to confirm the identification of the male of the species. There is some degree of ontogenic variation that might be encountered in both the species, as is apparent from the photographic records (Figures 1,2). During our sampling, we mainly encountered pruinosed specimens; therefore, we have not commented on the ontogenic variation. Detailed studies are required to understand ontogenic changes in the body coloration of the Elattoneura damselflies. Our comparative morphology analysis indicates that E. nigerrima is larger than E. tetrica hence rejecting Fraser's size hypothesis. We, however, find that E. nigerrima has relatively shorter forewings and hindwings than E. tetrica. The original short description of E. nihari (Mitra 1995) and the unavailability of intact specimens (Figure 5) made the comparison among the three species difficult. Therefore, we could not determine the degree of dissimilarity between the three Peninsular Indian Elattoneura. Using a molecular genetics approach in future studies will be useful to get a comprehensive picture.

\section{Revised geographical distribution}

Our revision of the spatial distribution of E. nigerrima and E. tetrica suggests that E. nigerrima is widespread across Peninsular India, occurring south of Satara, partially rejecting Fraser's distribution hypothesis. E. nigerrima is reported from Central (Madhya Pradesh) and Western (Maharashtra and Gujarat) India (Supplementary Table 1) and according to Fraser (1933), its distribution does not descend south of Satara. However, in the current study, we collected specimens of E. nigerrima at Amba and Agumbe, localities which are south of Satara, hence extending the species distribution into the Central Western Ghats (Figure 4). We found E. nigerrima in Telangana and Odisha States, extending the species distribution in Eastern India. These records suggest that E. nigerrima is much more widespread than previously thought. The lack of spatial data on E. nigerrima is perhaps due to the lack of clear taxonomic treatment. Elattoneura tetrica is known to be restricted to the Western 


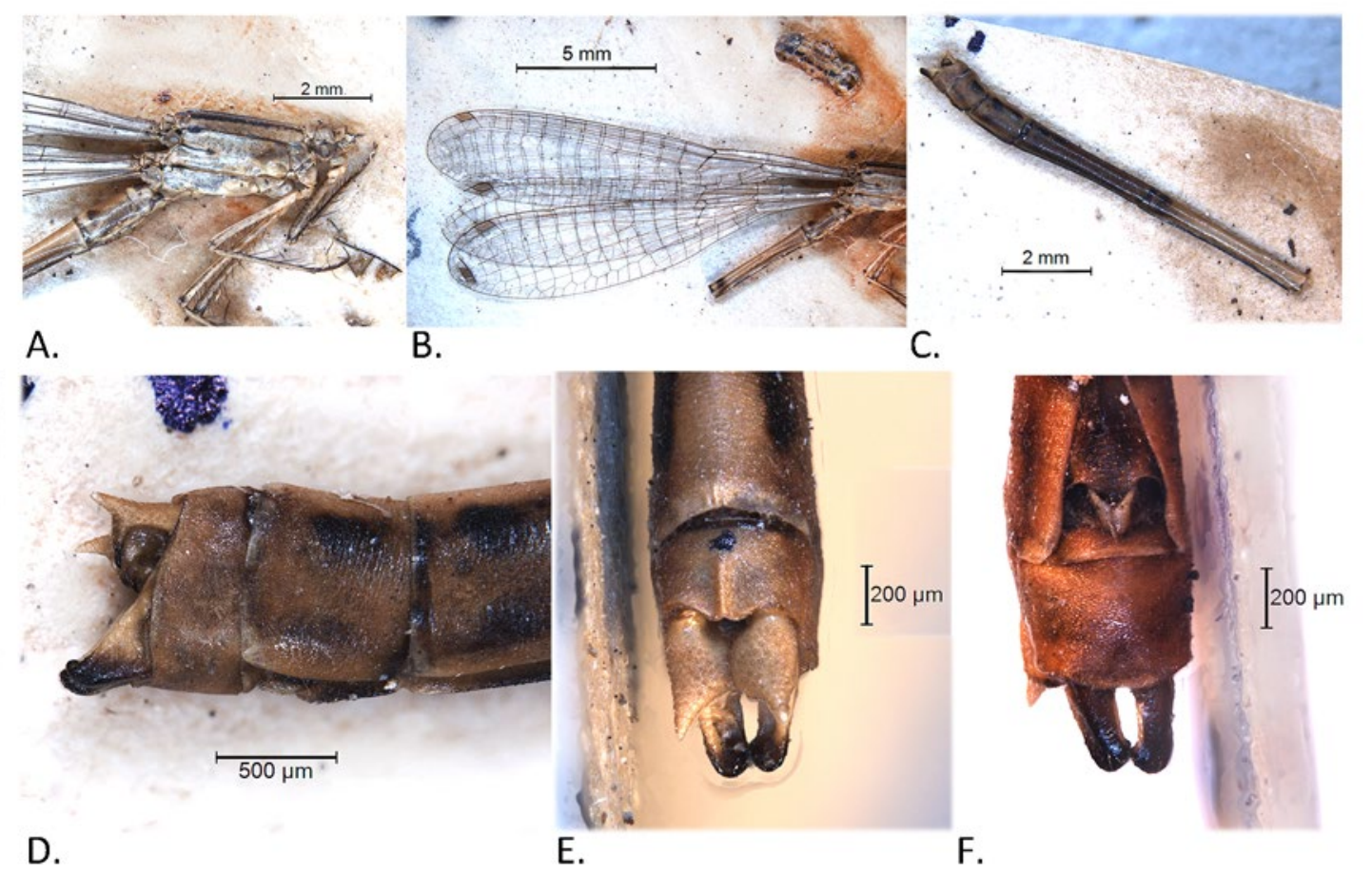

Figure 5. Scans of E. nihari type specimen accessed from the Zoological Survey of India, Kolkata, India (catalogue: 4096/H13). A: lateral view of thorax, B: wings, C: abdomen, D: lateral view of anal appendages, E: dorsal view of anal appendages, F: ventral view of anal appendages.

Ghats and has been recorded from Kerala, Karnataka and Goa (Supplementary Table 1). We also recorded it from Southwest Maharashtra, extending the species distribution slightly northwards in the Northern Western Ghats. Surprisingly, Mitra \& Babu (2009) recorded E. tetrica and Zia et al. (2011) recorded E. atkinsoni, E. nigerrima, E. tetrica and E. souteri from Pakistan. Considering the records of Zia et al. (2011), the first two species are usually considered to be endemic to India while the latter two are endemic to the Western Ghats (Mitra, 2002; Babu et al., 2013). We believe these records are likely to be a case of misidentification (Kalkman et al. 2020); however, a thorough investigation needs to be conducted given the uncertainty in species geographical limits. We found that $E$. nigerrima and E. tetrica are largely allopatric in Peninsular India. Elattoneura nigerrima is primarily distributed in the drier parts of Deccan and eastern catchments of the Western Ghats, with a few records from wet areas such as Agumbe and the latter in the climatically wetter regions of the Western Ghats, in line with Mitra (2003). Our limited observations point towards possibly specific habitat requirements of E. nigerrima and E. tetrica, given their occurrences in different bioclimatic zones (Supplementary Table 5).

\section{Conservation implications}

Availability of EOO and AOO data from this paper, for both E. nigerrima and E. tetrica, mandates modification in their current IUCN status. Elattoneura nigerrima is listed as Data Deficient species (Kakkasery, 2013). We recommend changing the status to Least Concern, given the widespread nature of the species. We recommend revising the status of E. tetrica to Vulnerable under the range criteria B1 \& B2a, B2b (AOO $<2000 \mathrm{~km}^{2}, \mathrm{EOO}=21,735 \mathrm{~km}^{2}, \leq 10$ locations) (IUCN Standards and Petitions Committee, 2019) after due scrutiny by IUCN reviewers and until further information becomes available. The current geographical distribution of the species is highly clustered. The species is localized and vulnerable to on-going agricultural expansion, pollution, and forest fragmentation within the Western Ghats (Kakkasery, 2011). Correct identification of the species is the first step to 
undertake any studies on the respective taxa (Pires \& Marinoni, 2010). The re-description provided here will also help reduce errors in identification and promote the collection of accurate data on $E$. nigerrima and E. tetrica. Such research can be further supplemented with ecological studies such as understanding natural history and habitat requirements which are important for formulating conservation management plans.

The new information provided here with a detailed morphological description and morphometric data and revised geographical distribution will help identify similar-looking E. nigerrima and $E$. tetrica. Our work highlights that update in taxonomic literature is the need of the hour, especially for thought-to-be-endemic species with uncertain threat status.

\section{Acknowledgments}

We thank Ben Price (British Museum of Natural History) for providing the images of holotypes and paratypes of E. nigerrima and E. tetrica. We thank Dhiraj Halali (Goa), Kaushal Patel (Gujarat), Vinayan Nair (Kerala), and Dattaprasad Sawant (Maharashtra) for observing and reporting Elattoneura damselflies from various localities in India. PD and KAS thank Director-ZSI for permission to study and photograph the E. nihari type specimen. We would like to thank Rory Dow and an anonymous referee for reviewing the manuscript.

\section{Funding}

The project was self-funded.

\section{References}

Babu, R., Subramanian, K.A., \& Nandy, S. (2013). Endemic Odonates of India. Records of Zoological Survey of India, 347, 1-65.

Bickford, D., Lohman, D.J., Sodhi, N.S., Ng, P.K., Meier, R., Winker, K., Ingram, K.K., \& Das, I. (2007). Cryptic species as a window on diversity and conservation. Trends in Ecology \& Evolution, 22,148-155. https://doi.org/10.1016/j.tree.2006.11.004

Cardoso, P., Terry L. E., Paulo, A.V. B., \& Tim, R. N. (2011). The seven impediments in invertebrate conservation and how to overcome them. Biological Conservation, 144, 2647-2655. https://doi. org/10.1016/j.biocon.2011.07.024

Chenuil, A., Cahill, A.E., Délémontey, N., du Luc, E.D.S., \& Fanton, H. (2019). Problems and questions posed by cryptic species. A framework to guide future studies. In E. Casetta, J. Marques da Silva, \& D. Vecchi (Eds.), From Assessing to Conserving Biodiversity (pp. 77-106). Springer, Switzerland. https://doi.org/10.1007/978-3-030-10991-2 4

Chesters. D. (2017). Construction of a species-level tree of life for the insects and utility in taxonomic profiling. Systems Biology, 66, 426-439. https://doi.org/10.1093/sysbio/syw099

Delić, T., Trontelj, P., Rendoš, M., \& Fišer, C. (2017). The importance of naming cryptic species and the conservation of endemic subterranean amphipods. Scientific Reports, 7, 1-12. https://doi.org/10.1038/ s41598-017-02938-z

Dow, R.A. (2009). Elattoneura nihari. IUCN Red List of Threatened Species. Version 2014.3. Retrieved March 12, 2015 from www.iucnredlist.org. https://www.iucnredlist.org/species/163817/5655866

Fraser, F.C. (1933). The Fauna of India, including Ceylon and Burma: Odonata (Vol. 1). Taylor and Francis, UK.

Gadagkar, R., Chandrashekara, K., \& Nair, P. (1989). Insect species diversity in the tropics: sampling methods and a case study. Journal of Bombay Natural History Society, 87, 337-353. http://repository.ias.ac.in/75475/

Garrison, R.W., von Ellenrieder, N., \& Louton, J.A. (2010). Damselfly genera of the New World: an illustrated and annotated key to the Zygoptera (490 pp). The Johns Hopkins University Press, Baltimore, Maryland, USA. 
Godfray, H.C.J., Lewis, O.T., \& Memmott, J. (1999). Studying insect diversity in the tropics. In D.M. Newbery, T.H. Clutton-Brock, \& G.T. Prance (Eds.), Changes and Disturbance in Tropical Rainforest in South-East Asia (pp 87-100). Imperial College Press, UK. https://doi.org/10.1142/9781848160125 0008

Hanusz, Z., Tarasinska, J., \& Zielinski, W. (2016). Shapiro-Wilk test with known mean. REVSTATStatistical Journal, 14, 89-100.

IUCN Standards and Petitions Committee. (2019). Guidelines for Using the IUCN Red List Categories and Criteria. Version 14. Prepared by the Standards and Petitions Committee. Downloadable from http://www.iucnredlist.org/documents/RedListGuidelines.pdfJoshi, S., Dawn, P., Roy, P., \& Kunte, K. (eds). (2020). Odonata of India, v. 1.48. Indian Foundation for Butterflies. https://www.indianodonata.org/ 4th April 2020.

Joshi, S., P. Dawn, P. Roy, and K. Kunte (eds.). (2020). Odonata of India, v. 1.57. Indian Foundation for Butterflies. Retrieved April 2, 2020 from https://www.indianodonata.org/

Kakkasery, F. (2013). Elattoneura nigerrima. IUCN Red List of Threatened Species. Version 2014.3. RetrievedMarch 12,2015 fromwww.iucnredlist.org. https://www.iucnredlist.org/species/175181/7118458

Kakkasery, F. (2011). Elattoneura tetrica. The IUCN Red List of Threatened Species. Version 3.1. Retrieved April2,2020 fromwww.iucnredlist.org.https://www.iucnredlist.org/species/175183/7118694

Kalkman, V.J., Babu, R., Bedjanič, M., Conniff, K., Gyeltshen, T., Khan, M.K., Subramanian, K.A., Zia, A., \& Orr, A.G. (2020). Checklist of the dragonflies and damselflies (Insecta: Odonata) of Bangladesh, Bhutan, India, Nepal, Pakistan and Sri Lanka. Zootaxa, 4849, 1-84.

Karger, D.N., Conrad, O., Böhner, J., Kawohl, T., Kreft, H., Soria-Auza, R.W., Zimmermann, N.E., Linder, H.P., \& Kessler, M. (2017). Climatologies at high resolution for the earth's land surface areas. Scientific Data, 4, 170122. https://doi.org/10.1038/sdata.2017.122

Laidlaw, F.F. (1917). A list of the dragonflies recorded from the Indian Empire with special reference to the collection of the Indian museum. Records of the Indian Museum, 13, 321-348. https://doi. org/10.5962/bhl.part.5864

Mitra, T.R. (1995). Odonata. In Fauna of Indravati Tiger Reserve. Fauna of Conservation Areas No. 6 (pp 31-44). Zoological Survey of India.

Mitra, T.R. (2002). Endemic Odonata of India. Records of the Zoological Survey of India, 100, 189-199.

Mitra, T.R. (2003). Ecology and biogeography of Odonata with special reference to Indian fauna. Records of the Zoological Survey of India, 202, 1-41.

Mitra, T.R., \& Babu, R. (2009). Previously unrecorded Odonata from salt ranges and Sind in Pakistan. Notulae Odonatologica, 7(4), 37-44.

Nelson, B., Ronayne, C. \& Thompson, R. (2011). Ireland Red List No.6: Damselflies \& Dragonflies (Odonata) (31 pp). National Parks and Wildlife Service, Department of the Environment, Heritage and Local Government, Dublin, Ireland.

Pires, A.C., \& Marinoni, L. (2010). DNA barcoding and traditional taxonomy unified through Integrative Taxonomy: a view that challenges the debate questioning both methodologies. Biota Neo, 10, 339-346. https://doi.org/10.1590/s1676-06032010000200035

Prasad, M., \& Varshey, R.K. (1995). A checklist of the Odonata of India including data on the larval studies. Oriental Insects, 29, 385-428. https://doi.org/10.1080/00305316.1995.10433748

QGIS Development Team. (2019). QGIS Geographic Information System. Open Source Geospatial Foundation Project. http://qgis.osgeo.org 4th April 2019.

R Core Team. (2013). R: A language and environment for statistical computing. R Foundation for Statistical Computing, Vienna, Austria. https://www.R-project.org/.

Schneider, C.A., Rasband, W.S., \& Eliceiri, K.W. (2012). NIH Image to ImageJ: 25 years of image analysis. Nature Methods, 9, 671-675. https://doi.org/10.1038/nmeth.2089

Schorr, M., \& Paulson, D. (2020). World Odonata List. Retrieved February 192020 from <www. pugetsound.edu>

Shapiro, S.S., \& Wilk, M.B. (1965). An analysis of variance test for normality (complete samples). Biometrika, 52, 591-611. https://doi.org/10.2307/2333709

Stork, N.E. (1988). Insect diversity: facts, fiction and speculation. Biological Journal of the Linnean Society, 35, 321-337. https://doi.org/10.1111/j.1095-8312.1988.tb00474.x

Subramanian, K.A. (2009). Dragonflies of India A field guide (180 pp). Vigyan Prasar, New Delhi, India.

Subramanian, K.A., \& Babu, R. (2017). A Checklist of Odonata of India. Version 3.0. Zoological Survey of India, Kolkata, India.

Sundar, S., Heino, J., Roque, F., Simaika, J.P., Melo, A.S., Tonkin, J.D., Nogueira, D.G., \& Silva, D.P.. (2020). Conservation of freshwater macroinvertebrate biodiversity in tropical regions. Aquatic Conservation: Marine and Freshwater Ecosystems, 30, 1238-1250. https://doi.org/10.1002/aqc.3326

Zia, A., Naeem, M., Rafi, M.A., Naz, F., Afsheen, S., \& Ilyas, M. (2011). Damselflies (Zygoptera: Odonata) of Pakistan: Part I. Journal of Insect Science, 11, 1-27. 